\title{
Evaluation of DOK5 as a susceptibility gene for type 2 diabetes and obesity in North Indian population
}

\author{
Rubina Tabassum', Anubha Mahajan', Ganesh Chauhan', Om Prakash Dwivedi', Saurabh Ghosh², Nikhil Tandon ${ }^{3 *}$, \\ Dwaipayan Bharadwaj ${ }^{*}$
}

\begin{abstract}
Background: Type 2 diabetes is a complex metabolic disorder with obesity being a major contributing factor in its development. Susceptibility loci for type 2 diabetes and obesity have been localized on different chromosomal regions by various genome-wide linkage scans. Of these chromosomal regions, 20q13 is one of the strongest linked regions for type 2 diabetes as well as obesity. On 20q13 lies DOK5 that seems to be a strong functional and positional candidate for type 2 diabetes and obesity because of its involvement in insulin signaling and immune responses. Hence, for the first time, we explored DOK5 as a potential type 2 diabetes and obesity susceptibility gene.

Methods: We sequenced 43 subjects for polymorphisms in functionally relevant regions of DOK5. A total of 10 SNPs that included 5 that were identified by sequencing and 5 additional SNPs from NCBI Variation Database were genotyped in 2,115 participants comprising of 1,073 patients with type 2 diabetes and 1,042 controls of IndoEuropean ethnicity from North India.

Results: We identified a novel variant in intron 7 referred to as DK176673. We found nominal association of three SNPs-rs6064099 (OR $=0.75, P=0.019)$, rs873079 $(\mathrm{OR}=0.76, P=0.036)$ and DK176673 $(\mathrm{OR}=1.55, P=0.037)$ with type 2 diabetes among normal-weight subjects $\left[\mathrm{BMl}<23 \mathrm{~kg} / \mathrm{m}^{2}\right.$ ]. The haplotype GGC harboring rs6068916, rs6064099 and rs873079 showed strong association with type 2 diabetes among normal-weight subjects ( $\mathrm{OR}=$ $\left.1.37, P / P_{\text {perm }}=5.8 \times 10^{-3} / 0.037\right)$. Association analysis with obesity revealed that $\mathrm{rs} 6064099$ is associated with reduced susceptibility for obesity $\left(\mathrm{OR}=0.48, P=6.8 \times 10^{-3}\right)$. Also, haplotype $\mathrm{GGC}$ conferred increased susceptibility for obesity $\left(\mathrm{OR}=1.27, \mathrm{P} / \mathrm{P}_{\text {perm }}=9.0 \times 10^{-3} / 0.039\right)$. Also, rs6064099 was significantly associated with reduced $\mathrm{BMl}$ [median(IQR) $=24.0(20.7-27.1)$ vs 23.9(20.2-26.8) vs 21.8(19.2-24.7) for GG vs GC vs CC, $P=7.0 \times 10^{-3}$ ].

Conclusions: We identified DOK5 as a novel susceptibility gene for obesity and type 2 diabetes in North Indian subjects. Association of DOK5 variants both with obesity and type 2 diabetes suggests that these variants might modulate type 2 diabetes susceptibility through obesity.
\end{abstract}

\section{Background}

Type 2 diabetes is a complex metabolic disorder characterized by impaired insulin secretion and action. Obesity is one of the major contributing factors in the development of type 2 diabetes. Though believed to be overlapping, the etiology of both type 2 diabetes and obesity are unclear. Gene identification is an important

\footnotetext{
* Correspondence: nikhil2811tandon@gmail.com; db@igib.res.in

${ }^{1}$ Functional Genomics Unit, Institute of Genomics and Integrative Biology (CSIR), Delhi- 110 007, India

${ }^{3}$ Department of Endocrinology, All India Institute of Medical Sciences, New Delhi-110 029, India
}

milestone in the understanding of disease pathophysiology, but has proven to be a difficult task for complex disorders such as type 2 diabetes. Multiple susceptibility loci on different chromosomal regions are believed to be involved in genetic etiology of type 2 diabetes.

Evidence for localization of susceptibility loci on different chromosomal regions for type 2 diabetes and obesity has been provided by various genome-wide linkage scans. Of these regions, 20q13 is one of the strongest candidate regions for type 2 diabetes which is documented to be linked to type 2 diabetes by more than 8

\section{Biomed Central}


genome wide studies in different populations [1-9]. The same region has also been shown to be linked to obesity by various studies [10-12]. However, till date there has been no clear evidence for localization of type 2 diabetes and obesity susceptibility genes on this region. Hence, exploration of $20 \mathrm{q} 13$ through positional candidate approach may facilitate identification of susceptibility genes for type 2 diabetes and obesity on this region.

The region 20q13 harbors DOK5 that encodes Dok5 which belongs to the Downstream of Kinases (DOK) family containing tandem pleckstrin homology-phosphotyrosine binding (PH-PTB) domains at the $\mathrm{N}$-terminal. Although the biological function of this docking protein is not very clear, Dok5 is shown to be one of the substrates in insulin signaling [13]. Dok5 contains a short C-terminus with potential sites for tyrosine phosphorylation that get phosphorylated in response to insulin and IGF1 [13]. Moreover, the highest expression of Dok5 has been detected in skeletal muscle which is the major tissue regulating metabolic homeostasis. Dok5 is also suggested to be involved in the regulation of immune response induced by $\mathrm{T}$ cells [14].

Because of its involvement in insulin signaling and immune responses which are the key modulating pathways in type 2 diabetes and obesity, DOK5 seems to be a convincing positional and functional candidate for type 2 diabetes and obesity. Therefore, here for the first time, we explored DOK5 as a potential type 2 diabetes and obesity susceptibility gene in North Indian population which has a high risk of developing type 2 diabetes.

\section{Methods}

\section{Subjects' recruitment}

A total of 2,115 unrelated subjects comprising of 1,073 patients with type 2 diabetes and 1,042 control subjects from North India belonging to Indo-European ethnicity were enrolled after obtaining written informed consent. Type 2 diabetic patients were recruited from Endocrinology clinic of All India Institute of Medical Sciences, New Delhi between the period of 2003 and 2008. Diagnosis of type 2 diabetes was done as per WHO criteria 2003 [15]. The control samples were collected by organizing 'Diabetes Awareness Camps' in the urban regions in and around Delhi. Subjects of $\geq 40$ years of age without family history of diabetes who had glycated hemoglobin (HbA1c) level $\leq 6.0 \%$ and fasting glucose level $<110 \mathrm{mg} / \mathrm{dL}$ were considered as controls. Detailed description of inclusion and exclusion criteria for cases and controls is provided previously [16]. Study was in accordance with the principles of the Helsinki Declaration and was approved by the Ethics Committees of the participating institutions.

\section{Anthropometric and biochemical characterization}

All the recruited subjects underwent anthropometric and biochemical measurements. Height, weight, waist and hip circumferences, and blood pressure were measured following standard guidelines before drawing blood. Body mass index (BMI) and waist to hip ratio (WHR) were calculated from these measurements. Based on their BMI, the subjects were categorized into two groups according to the BMI cut-offs for Asian populations: normal-weight (BMI $<23 \mathrm{~kg} / \mathrm{m}^{2}$ ) and overweight/obese subjects (BMI $\geq 23 \mathrm{~kg} / \mathrm{m}^{2}$ ) [17]. Venous blood samples were drawn after overnight fasting for biochemical measurements. Levels of glucose, HbA1c, insulin, C-peptide, total cholesterol, triglycerides (TG), high-density lipoprotein cholesterol (HDL-C), low-density lipoprotein cholesterol (LDL-C), urea, uric acid, creatinine and hsCRP were measured as described earlier $[16,18]$.

\section{Screening and identification of polymorphisms}

To identify novel variants if any, we sequenced approximately $5 \mathrm{~kb}$ region of $D O K 5$ including all exons, exonintron boundaries, putative promoter and UTRs in 43 samples of Indian Discovery panel [19]. Primers used were designed by Primer3 http://frodo.wi.mit.edu/primer3 that provides better primer design [20]. In the sequenced samples, we captured 9 SNPs including one novel variant in intron 7 (chromosomal position 53,266,929) that has never been reported earlier (referred here as DK176673) (Figure 1). From these, 5 SNPs (rs6098099, rs6068915, rs6064099, DK176673, rs2840) were selected for further genotyping. As SNPs in 3'UTR were very close, only one SNP (rs2840) was genotyped. Additionally, five more SNPs from NCBI Variation Database that includes rs6098009, rs6023307, rs6023357, rs6023367 and rs873079 were selected to cover the entire gene based on the selection criteria that includes functional significance, heterozygosity (MAF >0.05), information regarding tag SNPs and distance between the SNPs.

\section{Genotyping}

Genotyping of these 10 SNPs was performed using GoldenGate assay on Illumina platform (Illumina Inc., San Diego, CA, USA). The genotyping data obtained was subjected to extensive quality control that includes genotype confidence score of 0.25 , call frequency $>0.9$, GenTrans score $>0.6$, cluster separation score $>0.4$, MAF $>0.05$ and Hardy-Weinberg equilibrium (HWE) in controls $(P>0.01)$. Of the total case-control samples, 90 DNA samples had genotype call for less than $90 \%$ of the SNPs and hence were excluded. A total of 147 samples (7\%) were genotyped in duplicates and showed a consistency rate of $99.99 \%$ in genotype calls. SNP rs2840 failed 


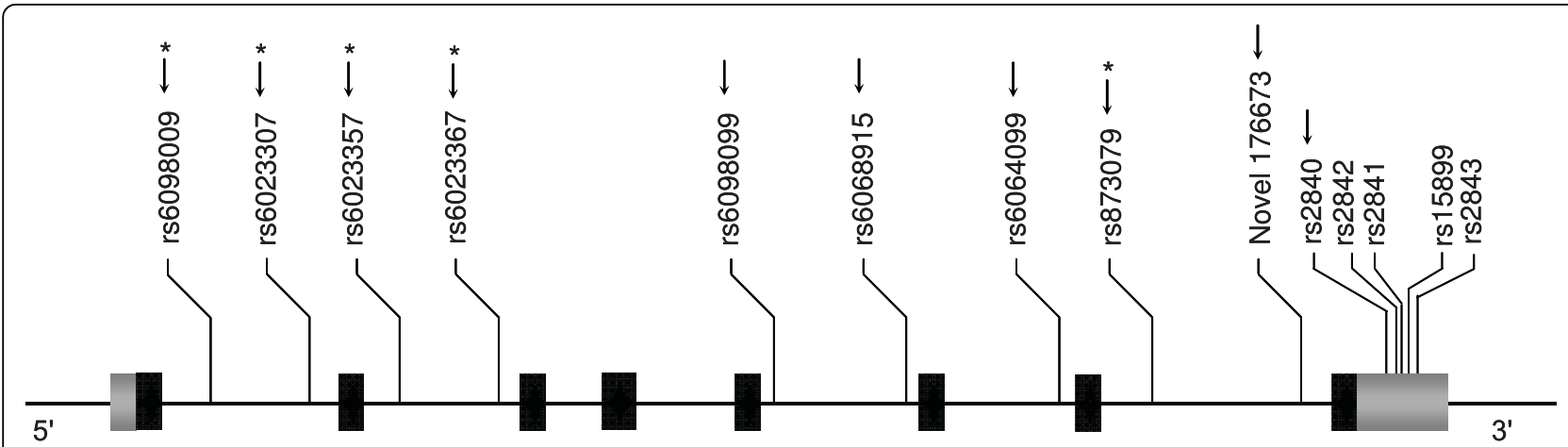

Figure 1 Gene structure of DOK5 representing SNPs identified in Indian population and selected for association analysis. SNPS marked with arrow were selected for association analysis. * indicates the SNPs selected from NCBI variation databases while other SNPs were identified by direct sequencing of the gene.

in Illumina assay and was genotyped using MALDI-TOF mass spectrometry (Sequenom, San Diego, CA, USA).

\section{Statistical Analysis}

Deviation from HWE at each locus was tested both among cases and controls separately using $\chi^{2}$ analyses. Association of genotypes with type 2 diabetes and obesity was assessed by logistic regression. Association analyses of genotypes with type 2 diabetes were also performed after stratification of cases and controls into normal-weight and over-weight/obese subjects. The analyses were adjusted for age, sex and BMI as appropriate. Odds ratios (ORs) are presented with respect to the minor alleles. Bonferroni correction was applied to correct for multiple comparisons and a $P$ value $<0.008$ was considered significant after correction. The uncorrected $P$ values are provided in the text. Association between genotypes and quantitative traits was determined using Kruskal-Wallis test only in control subjects. Haplotype analysis was carried out at 10,000 permutations using Haploview 4.0 [21]. Statistical power was determined using PS power and sample size program [22]. Our sample provided power of $69 \%-97 \%$ to detect association with ORs of 1.3-1.5 assuming MAF of 0.20 at level of significance of 0.05 . The statistical analyses were performed using SPSS version 17.0 (SPSS, Chicago, IL, USA) and PLINK v. 1.05 http://pngu.mgh.harvard.edu/ $\sim$ purcell/plink[23].

\section{Results}

\section{DOK5 polymorphisms}

We identified a total of 9 SNPs after sequencing the functionally significant regions of DOK5 including one novel SNP in intron 7 (referred as DK176673) and 8 reported SNPs-rs6098099 (Intron 5), rs6068915 (Intron 5), rs6064099 (Intron 6), rs2840 (5'UTR), rs2842 (5'UTR), rs2841 (5'UTR), rs15899 (5'UTR) and rs2843 (5'UTR) (Figure 1). As the 5 SNPs identified in 5'UTR region were very close to each other, only one (rs2840) was selected for further genotyping. Hence, of the 9 identified SNPs, 5 SNPs- rs6098099, rs6068915, rs6064099, DK176673, rs2840 were selected for further genotyping. Additionally, five more SNPs from NCBI Variation database that includes rs6098009 (Intron 1), rs6023307 (Intron 1), rs6023357 (Intron 2), rs6023367 (Intron 2) and rs873079 (Intron 7) were also selected for the complete coverage of gene region.

\section{DOK5 polymorphisms and type 2 diabetes}

A total of 10 SNPs were genotyped in the study population of 2,115 participants comprising of 1,073 patients with type 2 diabetes and 1,042 controls of Indo-European ethnicity from North India. The clinical characteristics of the study population are provided in Table 1. All the SNPs were in accordance with HWE (all $P>$ 0.01) both among cases and controls, except for rs 2840 that was eliminated from further analysis. SNPsrs6098009, rs6023307 and rs6098099 were found to be rare variants (MAF < 0.05 ) and were consequently excluded under the paradigm of a CVCD model. None of the DOK5 variants analyzed here showed association with type 2 diabetes (Table 2).

Obesity is a well known risk factor of type 2 diabetes and influence of BMI on the risk of development of type 2 diabetes has been consistently shown in number of studies [24]. Recently, we also showed variability in the risk of type 2 diabetes among individuals in different BMI strata [16,25]. This implies that the etiology of type 2 diabetes might be different in normal-weight individuals and overweight/obese individuals. Therefore, we segregated the subjects into two groups based on BMI: Normal-weight (BMI $\left.<23 \mathrm{~kg} / \mathrm{m}^{2}\right)$ and overweight/obese $\left(\mathrm{BMI} \geq 23 \mathrm{~kg} / \mathrm{m}^{2}\right)$. Type 2 diabetes patients among normal-weight and over-weight/obese groups had median age of 55 years with median BMI of $21.3 \mathrm{~kg} / \mathrm{m}^{2}$ and 53 years of median age with median BMI of $26.5 \mathrm{~kg} / \mathrm{m}^{2}$ 
Table 1 Anthropometric and clinical characteristics of the study population

\begin{tabular}{|c|c|c|}
\hline Characteristics & $\begin{array}{l}\text { Type } 2 \text { diabetic } \\
\text { patients }\end{array}$ & $\begin{array}{l}\text { Control } \\
\text { subjects }\end{array}$ \\
\hline N (Men/Women) & $1019(592 / 427)$ & $1006(606 / 400)$ \\
\hline Age (years) & $53(45-62)$ & $50(44-60)$ \\
\hline \multicolumn{3}{|l|}{ BMI $\left(\mathrm{Kg} / \mathrm{m}^{2}\right)$} \\
\hline Men & $23.8(22.0-26.0)$ & $23.1(20.1-25.7)$ \\
\hline Women & $26.7(24.2-29.2)$ & $25.0(21.1-28.5)$ \\
\hline \multicolumn{3}{|l|}{ WHR } \\
\hline Men & $1.0(0.97-1.03)$ & $0.97(0.92-1.0)$ \\
\hline Women & $1.0(0.97-1.03)$ & $0.86(0.82-0.92)$ \\
\hline Systolic BP (mmHg) & $130(130-140)$ & $120(112-132)$ \\
\hline Diastolic BP (mmHg) & $80(78-90)$ & $80(70-88)$ \\
\hline $\mathrm{HbA1c}(\%)$ & $7.8(6.5-9.4)$ & $5.2(4.9-5.6)$ \\
\hline Fasting Glucose (mmoles/L) & $7.9(6.4-10.3)$ & $4.9(4.5-5.3)$ \\
\hline Fasting Insulin $(\mu \mathrm{U} / \mathrm{mL})$ & $13.8(7.0-27.8)$ & $5.4(2.9-9.6)$ \\
\hline HOMA-IR & $5.2(2.3-9.6)$ & $1.2(0.6-2.0)$ \\
\hline C-peptide (ng/mL) & $2.7(1.7-4.1)$ & $1.6(1.1-2.2)$ \\
\hline hsCRP (mg/L) & $2.2(0.9-4.7)$ & $1.3(0.6-3.0)$ \\
\hline Total cholesterol (mg/dL) & $163(137-195)$ & $170(146-199)$ \\
\hline LDL-C (mg/dL) & $100(77-130)$ & $108(90-132)$ \\
\hline $\mathrm{HDL}-\mathrm{C}(\mathrm{mg} / \mathrm{dL})$ & $40(35-48)$ & $41(34-50)$ \\
\hline $\mathrm{TG}(\mathrm{mg} / \mathrm{dL})$ & $138(100-198)$ & $117(86-161)$ \\
\hline Urea (mg/dL) & $26(20-33)$ & $24(19-29)$ \\
\hline Uric acid (mg/dL) & $4.9(3.9-6.0)$ & $4.9(4.0-5.7)$ \\
\hline Creatinine (mg/dL) & $0.84(0.67-1.07)$ & $0.75(0.66-0.88)$ \\
\hline
\end{tabular}

Data are median values with interquartile ranges in parentheses. respectively. The control subjects among normal-weight and over-weight/obese groups had median age of 50 years with median BMI of $20.0 \mathrm{~kg} / \mathrm{m}^{2}$ and 50 years of median age with median BMI of $26.4 \mathrm{~kg} / \mathrm{m}^{2}$ respectively. Then, we compared the allelic and genotypic distributions among normal-weight cases and controls; and overweight/obese cases and controls (Table 2). We observed nominal association of rs6064099 and rs873079 among normal-weight subjects $[\mathrm{OR}=0.75$ $(P=0.019)$ and $0.76(P=0.036)]$. The association did not remain significant after adjusting for age, sex and BMI. Also, DK176673 was found to confer susceptibility to type 2 diabetes $(\mathrm{OR}=1.55, P=0.037)$ that was retained after adjustments for covariates $(P=0.043)$ but did not after applying multiple testing correction. Among over-weight/obese subjects, none of the SNPs showed significant effect on type 2 diabetes susceptibility.

SNPs rs6064099 and rs873079 were in strong LD ( $D^{\prime}=0.98$ and $\left.r^{2}=0.91\right)$. Among normal-weight individuals, haplotype GGC harboring major alleles of rs6068916, rs6064099 and rs873079 was more frequent among type 2 diabetes patients $(66.9 \%)$ as compared to control subjects (59.8\%). The GGC haplotype was found to confer increased susceptibility for type 2 diabetes $\left(\mathrm{OR}=1.37, P / P_{\text {perm }}=5.8 \times 10^{-3} / 0.037\right)$ among normalweight individuals (Table 3). Another haplotype CTT encompassing rs6064099, rs873079 and DK176673 showed reduction in type 2 diabetes susceptibility

Table 2 Association of DOK5 SNPs with type 2 diabetes in North Indian population

\begin{tabular}{|c|c|c|c|c|c|c|c|c|c|}
\hline \multirow[t]{2}{*}{ SNP } & \multicolumn{3}{|c|}{ Entire Sample set } & \multicolumn{3}{|c|}{ Normal-weight subjects } & \multicolumn{3}{|c|}{ Over-weight/obese subjects } \\
\hline & $\begin{array}{l}\text { Case: Control } \\
(1019: 1006)\end{array}$ & $\begin{array}{c}\text { OR } \\
(95 \% \mathrm{Cl}) \\
P \text { value } \\
\end{array}$ & $\begin{array}{c}\mathrm{OR}_{\text {adj }} \\
(95 \% \mathrm{Cl}) \\
P_{\text {adj }} \text { value }\end{array}$ & $\begin{array}{l}\text { Case: Control } \\
(295: 436)\end{array}$ & $\begin{array}{c}\text { OR } \\
(95 \% \mathrm{Cl}) \\
P \text { value } \\
\end{array}$ & $\begin{array}{c}\mathrm{OR}_{\text {adj }} \\
(95 \% \mathrm{Cl}) \\
P_{\text {adj }} \text { value }\end{array}$ & $\begin{array}{l}\text { Case: Control } \\
\text { (691: 561) }\end{array}$ & $\begin{array}{c}\text { OR } \\
(95 \% \mathrm{Cl}) \\
P \text { value } \\
\end{array}$ & $\begin{array}{c}\text { OR }_{\text {adj }} \\
(95 \% \mathrm{CI}) \\
P_{\text {adj }} \text { value }\end{array}$ \\
\hline rs6023357 (A/C) & $\begin{array}{l}\text { 814: } 822 \\
\text { 196: } 165 \\
\text { 7: } 16\end{array}$ & $\begin{array}{c}1.06 \\
(0.86-1.30) \\
0.597\end{array}$ & $\begin{array}{c}1.10 \\
(0.90-1.36) \\
0.355\end{array}$ & $\begin{array}{c}\text { 236: } 351 \\
\text { 56: } 77 \\
1: 6\end{array}$ & $\begin{array}{c}0.96 \\
(0.68-1.36) \\
0.825\end{array}$ & $\begin{array}{c}0.95 \\
(0.65-1.39) \\
0.799\end{array}$ & $\begin{array}{c}\text { 548: } 465 \\
\text { 137: } 87 \\
\text { 6: } 9\end{array}$ & $\begin{array}{c}1.17 \\
(0.90-1.52) \\
0.246\end{array}$ & $\begin{array}{c}1.16 \\
(0.89-1.50) \\
0.276\end{array}$ \\
\hline rs6023367 (G/A) & $\begin{array}{c}\text { 794: } 792 \\
\text { 218: } 202 \\
7: 11\end{array}$ & $\begin{array}{c}1.03 \\
(0.84-1.25) \\
0.810\end{array}$ & $\begin{array}{c}1.06 \\
(0.86-1.29) \\
0.606\end{array}$ & $\begin{array}{c}\text { 223: } 341 \\
\text { 70: } 92 \\
2: 3\end{array}$ & $\begin{array}{c}1.14 \\
(0.82-1.60) \\
0.432\end{array}$ & $\begin{array}{c}1.19 \\
(0.83-1.71) \\
0.335\end{array}$ & $\begin{array}{c}\text { 548: } 446 \\
\text { 138: } 107 \\
\text { 5: } 8\end{array}$ & $\begin{array}{c}0.97 \\
(0.75-1.26) \\
0.838\end{array}$ & $\begin{array}{c}0.97 \\
(0.75-1.26) \\
0.829\end{array}$ \\
\hline rs6068915 (C/T) & $\begin{array}{c}\text { 772: } 759 \\
\text { 229: } 217 \\
17: 28\end{array}$ & $\begin{array}{c}0.95 \\
(0.79-1.13) \\
0.533\end{array}$ & $\begin{array}{c}0.95 \\
(0.79-1.13) \\
0.562\end{array}$ & $\begin{array}{l}\text { 226: } 324 \\
\text { 63: } 98 \\
\text { 6: } 14\end{array}$ & $\begin{array}{c}0.87 \\
(0.65-1.17) \\
0.361\end{array}$ & $\begin{array}{c}0.91 \\
(0.66-1.24) \\
0.538\end{array}$ & $\begin{array}{l}\text { 525: } 430 \\
\text { 154: } 116 \\
11: 14\end{array}$ & $\begin{array}{c}0.99 \\
(0.79-1.25) \\
0.940\end{array}$ & $\begin{array}{c}0.97 \\
(0.77-1.23) \\
0.830\end{array}$ \\
\hline rs6064099 (G/C) & $\begin{array}{c}\text { 589: } 576 \\
\text { 366: } 369 \\
64: 60\end{array}$ & $\begin{array}{c}1.00 \\
(0.86-1.15) \\
0.948\end{array}$ & $\begin{array}{c}1.00 \\
(0.86-1.16) \\
0.990\end{array}$ & $\begin{array}{c}\text { 185: } 239 \\
\text { 95: } 161 \\
\text { 15: } 36\end{array}$ & $\begin{array}{c}0.75 \\
(0.59-0.95) \\
0.019\end{array}$ & $\begin{array}{c}0.78 \\
(0.60-1.01) \\
0.063\end{array}$ & $\begin{array}{c}\text { 385: } 331 \\
\text { 259: } 207 \\
\text { 47: } 23\end{array}$ & $\begin{array}{c}1.18 \\
(0.98-1.42) \\
0.080\end{array}$ & $\begin{array}{c}1.18 \\
(0.98-1.43) \\
0.080\end{array}$ \\
\hline rs873079 (G/A) & $\begin{array}{l}\text { 607: } 591 \\
\text { 356: } 364 \\
\text { 56: } 50\end{array}$ & $\begin{array}{c}0.99 \\
(0.86-1.15) \\
0.927\end{array}$ & $\begin{array}{c}0.99 \\
(0.85-1.15) \\
0.861\end{array}$ & $\begin{array}{l}\text { 191: } 248 \\
\text { 91: } 162 \\
\text { 13: } 26\end{array}$ & $\begin{array}{c}0.76 \\
(0.59-0.98) \\
0.036\end{array}$ & $\begin{array}{c}0.78 \\
(0.59-1.02) \\
0.065\end{array}$ & $\begin{array}{c}\text { 397: } 337 \\
\text { 253: } 201 \\
\text { 41: } 23\end{array}$ & $\begin{array}{c}1.14 \\
(0.94-1.37) \\
0.186\end{array}$ & $\begin{array}{c}1.14 \\
(0.94-1.38) \\
0.176\end{array}$ \\
\hline DK176673 (T/A) & $\begin{array}{c}\text { 847: } 807 \\
\text { 107: } 110 \\
\text { 6: } 1\end{array}$ & $\begin{array}{c}1.02 \\
(0.78-1.33) \\
0.900\end{array}$ & $\begin{array}{c}1.04 \\
(0.79-1.37) \\
0.791\end{array}$ & $\begin{array}{c}\text { 236: } 359 \\
\text { 38: } 43 \\
\text { 5: } 1\end{array}$ & $\begin{array}{c}1.55 \\
(1.03-2.34) \\
0.037\end{array}$ & $\begin{array}{c}1.58 \\
(1.01-2.46) \\
0.043\end{array}$ & $\begin{array}{c}\text { 584: } 441 \\
\text { 63: } 66 \\
\text { 1: } 0\end{array}$ & $\begin{array}{c}0.75 \\
(0.52-1.07) \\
0.116\end{array}$ & $\begin{array}{c}0.76 \\
(0.53-1.09) \\
0.132\end{array}$ \\
\hline
\end{tabular}

Data are presented as genotype counts. OR $(95 \% \mathrm{Cl})$ stands for odds ratio with $95 \%$ confidence interval assuming additive model. OR adj and $P_{\text {adj }}$ were calculated by logistic regression analysis after adjustments for age, sex and BMI. 
Table 3 Association of haplotype GGC with type 2 diabetes and obesity in North Indian population

\begin{tabular}{lcccc}
\hline Subjects & Haplotype Frequency & OR $(\mathbf{9 5} \% \mathbf{C l})$ & $\boldsymbol{P}$ value & $\boldsymbol{P}_{\text {perm }}$ value \\
\hline Type 2 diabetic patients & 66.9 & $1.37(1.10-1.70)$ & 0.0058 & 0.037 \\
Non-diabetic controls & 59.8 & & & 0.039 \\
\hline NW controls & 59.7 & $1.27(1.06-1.53)$ & 0.009 & \\
OW controls & 65.4 & & & \\
\hline
\end{tabular}

Haplotype frequencies are provided in percentages. NW stands for normal-weight subjects whereas OW stands for over-weight/obese subjects; OR (95\% Cl) stands for odds ratio with $95 \%$ confidence interval. $P_{\text {perm }}$ represents the $P$ values obtained after performing 10,000 permutations.

among normal-weight subjects, however did not remain significant after permutation analyses (haplotype frequencies of $19.5 \%$ and $24.1 \%$ among type 2 diabetes patients and controls respectively; $\mathrm{OR}=0.76, P / P_{\text {perm }}=$ $0.038 / 0.242$ ).

\section{DOK5 polymorphisms and obesity}

Association of DOK5 variants with obesity was assessed by considering BMI both as continuous and discrete trait $\left(\geq 23 \mathrm{~kg} / \mathrm{m}^{2}\right)$ among control subjects. SNP rs6064099 was significantly associated with reduced BMI $[$ median $(\mathrm{IQR})=24.0(20.7-27.1)$ vs $23.9(20.2-26.8)$ vs $21.8(19.2-24.7)$ for GG vs GC vs CC, $\left.P=7.0 \times 10^{-3}\right]$. Considering BMI as a discrete trait, we observed significant association of rs6064099 with obesity $(\mathrm{OR}=0.48$, $\left.P=6.8 \times 10^{-3}\right)$ that remained significant after adjusting for age and sex $\left(P=9.8 \times 10^{-3}\right)$. We also found significant association of GGC haplotype with obesity. GGC haplotype was over-represented among over-weight/ obese subjects (65.4\%) compared to normal-weight subjects (59.7\%), conferring risk for obesity with OR of 1.27 $\left[P=9.0 \times 10^{-3} / P_{\text {perm }}=0.039\right]$.

\section{DOK5 polymorphisms and quantitative clinical traits}

Further, we investigated association of DOK5 SNPs with quantitative traits related to type 2 diabetes including fasting glucose, $\mathrm{HbA}_{1 \mathrm{c}}$, insulin, C-peptide, hsCRP, total cholesterol, HDL, LDL, triglyceride, creatinine, urea and uric acid. For this, the clinical variables of only control subjects were compared across the genotypes of the SNPs as the disease status or treatment regime in patients might affect the estimation of these parameters. However, none of the SNPs was found to be significantly associated with the clinical traits investigated here (all $P>0.05$ ).

\section{Discussion}

Indian population represents the highest risk group for type 2 diabetes and related metabolic traits including obesity and cardiovascular diseases. A number of association studies have been performed in Indian population to evaluate the role of functional candidate genes, most of which involves replication of associations in other populations. Moreover, these efforts have not yielded any true susceptibility gene that causes type 2 diabetes in this high risk group. With the advent of genome-wide association (GWA) studies, there has been a sudden increase in the number of confirmed loci for type 2 diabetes [26]. However, these identified loci contribute only to a small proportion of expected number of involved genes [27]. Hence, along with the model free approach of GWA studies, positional candidate approach targeting genes with plausible functional relevance can substantially contribute to a better understanding of the complex disorders. Therefore, here, we investigated a potential positional and functional candidate gene, DOK5 on chromosomal region $20 \mathrm{q} 13$, to identify novel susceptibility gene for type 2 diabetes and obesity.

Association analysis of DOK5 SNPs revealed significant association of its variants with type 2 diabetes among normal-weight subjects. SNPs rs6064099 in intron 6 and rs873079 in intron 7 were found to reduce the susceptibility to type 2 diabetes among normalweight individuals. Also, the novel SNP DK176673 was found to confer susceptibility to type 2 diabetes. Normal-weight individuals harboring haplotype GGC of major alleles for SNPs rs6068915, rs6064099 and rs873079 were found to be more susceptible to type 2 diabetes. Hence, our data suggests that DOK5 might play a significant role in modulating the susceptibility of type 2 diabetes among normal-weight subjects in North Indian population. Our study further reinforces our earlier observations that etiologic mechanisms of pathophysiology of type 2 diabetes depend on BMI [11,24].

Consistent with earlier observations of linkage of 20 q13 with obesity, our study also provides added evidence for the localization of susceptibility gene for obesity in this region. We found strong association of rs6064099 with protection against obesity. Also, GGC haplotype was found to confer increased susceptibility to obesity. Association of DOK5 variants with obesity again suggests that these variants may modulate the susceptibility to type 2 diabetes through obesity.

It is interesting to note the GGC haplotype region harboring three SNPs rs6068916, rs6064099 and rs873079, encompasses exons 6 and 7 of DOK5 gene. In case if these associated SNPs are not true causal variants, there might be a causal or functionally relevant variant in LD with the associated SNPs influencing the 
risk of type 2 diabetes and obesity. Though we attempted to identify all the polymorphisms in exonic regions, there might be possibility of less common variants with higher relative risks in these regions that could not be captured in our sequenced samples. Hence, further evaluation of SNPs in DOK5 in a larger population might provide true susceptibility variant in DOK5 gene.

We would like to mention here that production of false positives in association studies due to population stratification and multiple comparisons might be plausible. With this in mind, our case and control subjects were recruited from a homogenous cluster in urban region of North India in accordance to a report of genetic landscape of the people of India [28]. From the clustering pattern, it was suggested that if cases and controls are both drawn from the same cluster, the effects of population stratification in disease association studies may be small. Another study analyzing Indian genetic variation and diversity also suggested that the effects of population heterogeneity on the production of false positives in association studies might be smaller in Indians than might be expected for such a geographically and linguistically diverse subset of the human population [29].

\section{Conclusions}

In conclusion, we identified DOK5 as a novel gene modulating the susceptibility of obesity and diabetes in North Indian population of Indo-European ethnicity. However, replication analyses of the variants showing association in this study are warranted to validate the findings. Moreover, other genetic variants in the gene might also play role in influencing the risk of type 2 diabetes. Therefore, future genetic and functional studies evaluating the association of genetic variants of DOK5 and deciphering their physiological effect and mechanisms are needed to further ascertain its role in the manifestation of type 2 diabetes.

\section{List of Abbreviations}

DOK5: Docking Protein 5; IGF1: Insulin like Growth Factor 1; PH-PTB: pleckstrin homology-phosphotyrosine binding domain; CVCD: Common Variant Common Disease; MAF: Minor Allele Frequency

\section{Acknowledgements}

We thank all the patients and healthy individuals for participating in the study. We also thank Mr. A.K. Sharma for his help in sample collection. We would like to acknowledge Indian Genome Variation Consortium. This study was supported by 'Diabetes mellitus-New drug discovery R\&D, molecular mechanisms and genetic \& epidemiological factors' (NWP0032-9) funded by Council of Scientific and Industrial Research (CSIR), Government of India. We thank Dr. Abhay Sharma (Institute of Genomics and Integrative Biology, CSIR) for critical evaluation of the manuscript.

\section{Author details}

${ }^{1}$ Functional Genomics Unit, Institute of Genomics and Integrative Biology (CSIR), Delhi- 110 007, India. ${ }^{2}$ Human Genetics Unit, Indian Statistical Institute,
Kolkata- 700 108, India. ${ }^{3}$ Department of Endocrinology, All India Institute of Medical Sciences, New Delhi-110 029, India.

\section{Authors' contributions}

RT and AM designed, processed, interpreted the data and wrote the manuscript. GC and OPD contributed in work design and manuscript writing. SG contributed in the statistical analysis of the data. DB and NT conceived and supervised the study and have contributed by critical evaluation of the study and improving the manuscript. All the authors read and approved the final manuscript.

\section{Competing interests}

The authors declare that they have no competing interests.

Received: 9 September 2009 Accepted: 27 February 2010

Published: 27 February 2010

\section{References}

1. Ji L, Malecki M, Warram JH, Yang Y, Rich SS, Krolewski AS: New susceptibility locus for NIDDM is localized to human chromosome 20q. Diabetes 1997, 46:876-881.

2. Bowden DW, Sale M, Howard TD, Qadri A, Spray BJ, Rothschild CB, Akots G, Rich SS, Freedman BI: Linkage of genetic markers on human chromosomes 20 and 12 to NIDDM in Caucasian sib pairs with a history of diabetic nephropathy. Diabetes 1997, 46:882-886

3. Zouali H, Hani EH, Philippi A, Vionnet N, Beckmann JS, Demenais F, Froguel P: A susceptibility locus for early-onset non-insulin dependent (type 2) diabetes mellitus maps to chromosome 20q, proximal to the phosphoenolpyruvate carboxykinase gene. Hum Mol Genet 1997, 6:1401-1408.

4. Ghosh S, Watanabe RM, Hauser ER, Valle T, Magnuson VL, Erdos MR, Langefeld CD, Balow J Jr, Ally DS, Kohtamaki K, Chines P, Birznieks G, Kaleta HS, Musick A, Te C, Tannenbaum J, Eldridge W, Shapiro S, Martin C, Witt A, So A, Chang J, Shurtleff B, Porter R, Kudelko K, Unni A, Segal L, Sharaf R, Blaschak-Harvan J, Eriksson J, Tenkula T, Vidgren G, Ehnholm C, Tuomilehto-Wolf E, Hagopian W, Buchanan TA, Tuomilehto J, Bergman RN, Collins FS, Boehnke M: Type 2 diabetes: evidence for linkage on chromosome 20 in 716 Finnish affected sib pairs. Proc Natl Acad Sci USA 1999, 96:2198-2203.

5. Klupa T, Malecki MT, Pezzolesi M, Ji L, Curtis S, Langefeld CD, Rich SS, Warram JH, Krolewski AS: Further evidence for a susceptibility locus for type 2 diabetes on chromosome 20q13.1-q13.2. Diabetes 2000, 49:2212-2216.

6. Permutt MA, Wasson JC, Suarez BK, Lin J, Thomas J, Meyer J, Lewitzky S, Rennich JS, Parker A, DuPrat L, Maruti S, Chayen S, Glaser B: A genome scan for type 2 diabetes susceptibility loci in a genetically isolated population. Diabetes 2001, 50:681-685

7. Luo TH, Zhao Y, Li G, Yuan WT, Zhao JJ, Chen JL, Huang W, Luo M: A genome-wide search for type II diabetes susceptibility genes in Chinese Hans. Diabetologia 2001, 44:501-506.

8. Mori Y, Otabe S, Dina C, Yasuda K, Populaire C, Lecoeur C, Vatin V, Durand E, Hara K, Okada T, Tobe K, Boutin P, Kadowaki T, Froguel P. Genome-wide search for type 2 diabetes in Japanese affected sib-pairs confirms susceptibility genes on $3 q, 15 q$, and $20 q$ and identifies two new candidate Loci on 7p and 11p. Diabetes 2002, 51:1247-1255.

9. Rotimi CN, Chen G, Adeyemo AA, Furbert-Harris P, Parish-Gause D, Zhou J, Berg K, Adegoke O, Amoah A, Owusu S, Acheampong J, AgyenimBoateng K, Eghan BA Jr, Oli J, Okafor G, Ofoegbu E, Osotimehin B, Abbiyesuku F, Johnson T, Rufus T, Fasanmade O, Kittles R, Daniel H, Chen $Y$, Dunston G, Collins FS, the Africa America Diabetes Mellitus (AADM) Study: A genome-wide search for type 2 diabetes susceptibility genes in West Africans: the Africa America Diabetes Mellitus (AADM) Study. Diabetes 2004, 53:838-841.

10. Lembertas AV, Pérusse L, Chagnon YC, Fisler JS, Warden $\mathrm{CH}_{\text {, Purcell- }}$ Huynh DA, Dionne FT, Gagnon J, Nadeau A, Lusis AJ, Bouchard C Identification of an obesity quantitative trait locus on mouse chromosome 2 and evidence of linkage to body fat and insulin on the human homologous region 20q. J Clin Invest 1997, 100:1240-1247.

11. Lee JH, Reed DR, Li WD, Xu W, Joo EJ, Kilker RL, Nanthakumar E, North M, Sakul H, Bell C, Price RA: Genome scan for human obesity and linkage to markers in 20q13. Am J Hum Genet 1999, 64:196-209. 
12. Hunt SC, Abkevich V, Hensel CH, Gutin A, Neff CD, Russell DL, Tran T, Hong X, Jammulapati S, Riley R, Weaver-Feldhaus J, Macalma T, Richards MM, Gress R, Francis M, Thomas A, Frech GC, Adams TD, Shattuck D, Stone S: Linkage of body mass index to chromosome 20 in Utah pedigrees. Hum Genet 2001, 109:279-285.

13. Cai D, Dhe-Paganon S, Melendez PA, Lee J, Shoelson SE: Two new substrates in insulin signaling, IRS5/DOK4 and IRS6/DOK5. J Biol Chem 2002, 278:25323-25330.

14. Favre $C$, Gérard $A$, Clauzier E, Pontarotti $P$, Olive D, Nunès JA: DOK4 and DOK5: new Dok-related genes expressed in human T cells. Genes Immun 2003, 4:40-45.

15. Expertcommittee on the diagnosis and classification of diabetes mellitus: Report of the expert committee on the diagnosis and classification of diabetes mellitus. Diabetes Care 2003, 26:S5-S20.

16. Tabassum R, Chavali S, Dwivedi OP, Tandon N, Bharadwaj D: Genetic variants of FOXA2: risk of type 2 diabetes and effect on metabolic traits in North Indians. J Hum Genet 2008, 53:957-965.

17. WHO Expert Consultation: Appropriate body-mass index for Asian populations and its implications for policy and intervention strategies. Lancet 2004, 363:157-163.

18. Tabassum R, Chavali S, Mahajan A, Ghosh S, Madhu SV, Tandon N, Bharadwaj D: Association analysis of TNFRSF1B polymorphisms with type 2 diabetes and its related traits in North India. Genomic Med 2008, 2:93-100.

19. Indian Genome Variation Consortium: The Indian Genome Variation database (IGVdb): a project overview. Hum Genet 2005, 118:1-11.

20. Chavali S, Mahajan A, Tabassum R, Maiti S, Bharadwaj D: Oligonucleotide properties determination and primer designing: a critical examination of predictions. Bioinformatics 2005, 21:3918-3925.

21. Barrett JC, Fry B, Maller J, Daly MJ: Haploview: analysis and visualization of LD and haplotype maps. Bioinformatics 2005, 21:263-265.

22. Dupont WD, Plummer WD: PS power and sample size program available for free on the Internet. Control Clin Trials 1997, 18:274.

23. Purcell $S$, Neale B, Todd-Brown K, Thomas L, Ferreira MA, Bender D, Maller J, Sklar P, de Bakker PI, Daly MJ, Sham PC: PLINK: a tool set for wholegenome association and population-based linkage analyses. Am J Hum Genet 2007, 81:559-575.

24. Cauchi S, Nead KT, Choquet H, Horber F, Potoczna N, Balkau B, Marre M, Charpentier G, Froguel P, Meyre D: The genetic susceptibility to type 2 diabetes may be modulated by obesity status: implications for association studies. BMC Med Genet 2008, 9:45.

25. Mahajan A, Tabassum R, Chavali S, Dwivedi OP, Chauhan G, Tandon N, Bharadwaj D: Obesity-dependent association of TNF-LTA locus with type 2 diabetes in North Indians. J Mol Med 2010.

26. McCarthy Ml: Casting a wider net for diabetes susceptibility genes. Nat Genet 2008, 40:1039-1040.

27. Zeggini E, Scott LJ, Saxena R, Voight BF, Marchini JL, Hu T, de Bakker Pl, Abecasis GR, Almgren P, Andersen G, Ardlie K, Boström KB, Bergman RN, Bonnycastle LL, Borch-Johnsen K, Burtt NP, Chen H, Chines PS, Daly MJ, Deodhar P, Ding CJ, Doney AS, Duren WL, Elliott KS, Erdos MR, Frayling TM, Freathy RM, Gianniny L, Grallert H, Grarup N, Groves CJ, Guiducci C, Hansen $T$, Herder $C$, Hitman GA, Hughes TE, Isomaa B, Jackson AU, Jørgensen T, Kong A, Kubalanza K, Kuruvilla FG, Kuusisto J, Langenberg C, Lango H, Lauritzen T, Li Y, Lindgren CM, Lyssenko V, Marvelle AF, Meisinger C, Midthjell K, Mohlke KL, Morken MA, Morris AD, Narisu N, Nilsson P, Owen KR, Palmer CN, Payne F, Perry JR, Pettersen E, Platou C, Prokopenko I, Qi L, Qin L, Rayner NW, Rees M, Roix JJ, Sandbaek A, Shields B, Sjögren M, Steinthorsdottir V, Stringham HM, Swift AJ, Thorleifsson G, Thorsteinsdottir U, Timpson NJ, Tuomi T, Tuomilehto J, Walker M, Watanabe RM, Weedon MN, Willer CJ, Wellcome Trust Case Control Consortium, Illig T, Hveem K, Hu FB, Laakso M, Stefansson K, Pedersen O, Wareham NJ, Barroso I, Hattersley AT, Collins FS, Groop L, McCarthy Ml, Boehnke M, Altshuler D: Meta-analysis of genome-wide association data and large-scale replication identifies additional susceptibility loci for type 2 diabetes. Nat Genet 2008, 40:638-645.

28. Indian Genome Variation Consortium: Genetic Landscape of the People of India: a Canvas for Disease Gene Exploration. J Genet 2008, 87:3-20.

29. Rosenberg NA, Mahajan S, Gonzalez-Quevedo C, Blum MG, Nino-Rosales L, Ninis V, Das P, Hegde M, Molinari L, Zapata G, Weber JL, Belmont JW, Patel PI: Low levels of genetic divergence across geographically and linguistically diverse populations from India. PLOS Genet 2006, 2:e215.

\section{Pre-publication history}

The pre-publication history for this paper can be accessed here: http://www. biomedcentral.com/1471-2350/11/35/prepub

doi:10.1186/1471-2350-11-35

Cite this article as: Tabassum et al: Evaluation of DOK5 as a susceptibility gene for type 2 diabetes and obesity in North Indian population. BMC Medical Genetics 2010 11:35.

\section{Submit your next manuscript to BioMed Central and take full advantage of:}

- Convenient online submission

- Thorough peer review

- No space constraints or color figure charges

- Immediate publication on acceptance

- Inclusion in PubMed, CAS, Scopus and Google Scholar

- Research which is freely available for redistribution

Submit your manuscript at www.biomedcentral.com/submit
Biomed Central 